\title{
Effect of eucalyptus proximity and weed presence on soybean grown in a CFI system
}

\author{
Efeito da proximidade ao eucalipto e da presença de plantas daninhas sobre a soja \\ cultivada em sistema ILF
}

\begin{abstract}
Ricardo Fagundes MARQUES ${ }^{1}$; Sidnei Roberto de MARCHI; Guilherme Henrique Rodrigues PINHEIRO; Prissila Pereira do Santos ARAÚJO ${ }^{4}$; Rodrigo Marques de SOUZA ${ }^{5}$

${ }^{1}$ Autor para correspondência: Eng. Agr., Mestre em Produção Vegetal, Universidade Federal de Goiás, Regional Jataí, Rodovia BR-364 Setor Francisco Antônio 75801615 - Jataí, GO - Brasil, rfmarques94@gmail.com

${ }^{2}$ Eng. Agr., Doutor em Agronomia, Universidade Federal de Mato Grosso, Campus do Araguaia, sidneimarchi.ufmt@gmail.com

${ }^{3}$ Eng. Agr., Mestrando em Produção Vegetal, Universidade Federal de Goiás, Regional Jataí, grhpinheiro@gmail.com

4 Eng. Agr., Mestranda em Produção Vegetal, Universidade Federal de Goiás, Regional Jataí, prissila_araujo@hotmail.com

${ }^{5}$ Graduando em Agronomia, Universidade Federal de Mato Grosso, Campus do Araguaia, rodrigomarques_agro@hotmail.com
\end{abstract}

Recebido em: 29-03-2019; Aceito em: 28-08-2019

\begin{abstract}
The growing demand for food, bioenergy, and forest products requires solutions that encourage socioeconomic development without compromising the sustainability of natural resources. It is in this scenario that the integration strategy has been pointed as an alternative to reconcile conflicts of interest. This study evaluates possible changes in nodulation, photosynthetic efficiency, and yield of soybean grown in a Crop-Forest Integration system with eucalyptus as a tree component. The experiment was conducted in a randomized complete block design with four replications. Treatments were arranged in a $3 \times 5$ factorial scheme, corresponding to three sowing conditions (near eucalyptus stands; 3.0 meters away from the stands, in a clean seedbed; and $3.0 \mathrm{~m}$ away from the stands, among the vegetation) and five points of distance between soybean and the stands, represented by planting rows, namely: $1^{\text {st }}, 2^{\text {nd }}, 3^{\text {rd }}, 11^{\text {th }}$, and $21^{\text {st }}$ row. We evaluated morphophysiological and productive variables of soybean plants. Soybean cultivation near eucalyptus stands does not affect the number and dry matter of soybean nodules, but reduces yield in the first two rows. The presence of weeds in the range between eucalyptus stands and soybean plants impaired the photochemical apparatus and the chlorophyll $\alpha$ fluorescence of soybean crop, decreasing the shoot dry matter accumulation, number and dry matter of nodules, and yield of plants present in the first planting rows.
\end{abstract}

Additional keywords: Eucalyptus sp; Glycine max; photosynthesis, Rhizobium.

\begin{abstract}
Resumo
A demanda crescente por alimentos, bioenergia e produtos florestais requer soluções que permitam incentivar 0 desenvolvimento socioeconômico sem comprometer a sustentabilidade dos recursos naturais. É nesse cenário que a estratégia de integração tem sido apontada como alternativa para conciliar esses conflitos de interesse. $O$ objetivo deste trabalho foi avaliar possíveis alterações na nodulação, eficiência fotossintética e produtividade de soja cultivada no sistema de integração Lavoura-Floresta tendo o eucalipto como componente arbóreo. O experimento foi conduzido em delineamento experimental de blocos ao acaso, com quatro repetições e os tratamentos dispostos em esquema fatorial $3 \times 5$, sendo três condições de semeadura (próximo ao renque, semeada a 3,0 metros de distância do renque no limpo e 3,0 metros de distância do renque no mato) e cinco pontos de distâncias das plantas de soja ao renque, representado por linhas de plantio, a saber: 1aㅡ, 2aㅡ, 3aㅡ, 11aㅡ e 21aㅡ linha. Foram avaliadas as variáveis morfofisiológicas e produtivas das plantas de soja. Constatou-se que o cultivo de soja realizado próximo ao renque de eucalipto não interfere no número e matéria seca de nódulos, mas reduz a produtividade nas duas primeiras linhas de semeadura. A presença de plantas daninhas na faixa localizada entre o renque e a soja ocasionou danos ao aparato fotoquímico e nas características da fluorescência da clorofila $\alpha$ da cultura diminuindo o acúmulo de matéria seca da parte aérea, número e a matéria seca dos nódulos e a produtividade das plantas presentes nas primeiras linhas de semeadura.
\end{abstract}

Palavras-chave adicionais: Eucalyptus SP; fotossíntese; Glycine max; Rhizobium. 


\section{Introduction}

Monoculture and inadequate agronomic cultural practices have caused yield losses, increased insect and disease occurrence, and degradation of soil and natural resources. Crop-Livestock-Forest Integration (CLFI) represents a new approach to these systems, aiming to combine sustainable production with preservation of agroecosystems (Macedo, 2009).

The growing demand for food, bioenergy, and forest products, as opposed to the need to reduce deforestation and mitigate greenhouse gas emissions, requires solutions that enable socioeconomic development without compromising the sustainability of natural resources. Intensified land use in agricultural areas and increased efficiency of production systems can help harmonize these interests. In this scenario, the CLFI strategy has been pointed as an alternative to reconcile conflicts of interest (Balbino et al., 2011).

Productive areas using this integrated production technology are currently expanding in the country, with a growth trend in the coming years (Wink et al., 2018). According to current estimates, the area under CLFI systems in Brazil exceeds 11.5 million hectares. Mato Grosso State accounts for 1.5 million hectares, or $13 \%$ of the national total. However, the forest component is estimated to be present in only $10 \%$ of this area (Tonini et al., 2016).

There are different production systems based on Crop-Livestock-Forest Integration, which are premised on the integrated presence of at least two of the three components, configuring as CLFI modalities the following arrangements: livestock-forest integration (LFI), crop-livestock integration (CLI), and crop-forest integration (CFI) (Soratto et al., 2011).

The genus Eucalyptus is one of the most widely used tree components in CLFI areas. Its adoption in this type of cropping system is due to the large number of genotypes/phenotypes available, adaptation to Brazilian climatic conditions, multiplicity of uses in timber and nontimber products, rapid growth, and high yield (Tonini et al., 2016).

The agricultural components generally used are already traditional crops such as corn, sorghum, coffee, millet, beans, soybeans, rice, and sunflower. However, soybean cultivation is still the most recommended in integration areas due to operational ease, low production cost, highly productive and adapted cultivars, and short life cycle (Franchini et al., 2014).

Notwithstanding, research results on the performance of crops under intercropping systems are incipient, especially between forest species and annual grain crops. There are still many doubts about possible depressive effects caused by tree species on crop performance (Almeida et al., 2014). Therefore, further research is needed to help better understand the relationship between trees and the different components of CLFI systems to define a minimum distance between tree rows and the agricultural component that can favor positive interactions (Diel et al., 2014).
Furthermore, there are no studies in the literature that indicate whether the presence of weeds between tree and agricultural components can influence the morphological and productive characteristics of plants. The presence of weeds in areas cultivated with soybeans is known to influence important agronomic characteristics resulting in reduced yield due to interference caused by competition when resources are scarce (Moraes et al., 2009).

Given the above, the present study analyzes how much the eucalyptus (tree component) and the presence of weeds influence photosynthesis, nodulation, and yield characteristics of soybean (crop component) grown in a Crop-Forest Integration (CFI) system.

\section{Materials and methods}

The experimental phase of this project was conducted in a CFI (Crop-Forest Integration) Technology Reference Unit (URT) in Barra do Garças city, Mato Grosso State, whose geographical coordinates are $15^{\circ} 00^{\prime} 58.1^{\prime \prime} \mathrm{S}$ and $52^{\circ} 15^{\prime} 58.5^{\prime \prime} \mathrm{W}$. According to the Köppen classification, the climate of the region is Aw, with average temperatures over $27^{\circ} \mathrm{C}$ from November to February, and over $18{ }^{\circ} \mathrm{C}$ from June to August. Annual rainfall averages are between $1000 \mathrm{~mm}$ and 1500 $\mathrm{mm}$, distributed in two well-defined periods: heavy rain season from October to March, and clear dry season from April to September (Marchi et al., 2017).

The experiment was conducted in a randomized complete block design with four replications. Treatments were arranged in a $3 \times 5$ factorial scheme, with three sowing conditions as sources of variation (sown $0.45 \mathrm{~m}$ away from the row - "near"; sown $3.0 \mathrm{~m}$ away from the row with subsequent weed control "clean"; and sown 3.0 m away from the row without later weed control - "vegetation") and five points of distance between soybean plants and the stands, represented by planting rows of $10.0 \mathrm{~m}$ in length, namely: $1^{\text {st }}(0.45 \mathrm{~m}), 2^{\text {nd }}(0.90 \mathrm{~m}), 3^{\text {rd }}(1.35 \mathrm{~m}), 11^{\text {th }}(4.95 \mathrm{~m})$, and $21^{\text {st }}$ row $(9.45 \mathrm{~m})$ (Figure 1 ).

Soil composite samples were collected and sent for laboratory analysis. The chemical and physical characteristics of the soil were: $\mathrm{pH}\left(\mathrm{CaCl}_{2}\right)$ of $4.8 ; 22.0$ $\mathrm{g} \mathrm{dm}^{-3}$ organic matter; $4.0 \mathrm{mg} \mathrm{dm}^{-3} \mathrm{P}_{\text {resin }} ; 44.6 \% \mathrm{~V} ; \mathrm{K}$, $\mathrm{Ca}, \mathrm{Mg}$, and $\mathrm{H}+\mathrm{Al}$ contents of $3.1,18.0,6.0$, and 34.0 mmolc dm${ }^{-3}$, respectively; $706 \mathrm{~g} \mathrm{~kg}^{-1}$ sand; $85 \mathrm{~g} \mathrm{~kg}^{-1}$ silt; and $209 \mathrm{~g} \mathrm{~kg}^{-1}$ clay. Based on soil analysis, the fertility and acidity corrections consisted of $255 \mathrm{~kg} \mathrm{ha}^{-1}$ of the 00-30-10 formulation in the sowing furrow and a cover fertilization of $120 \mathrm{~kg} \mathrm{ha}^{-1} \mathrm{KCl}$ at 30 days after soybean emergence (DAE).

The soybean variety MONSOY 8866 was used at a sowing density of 15 plants $\mathrm{m}^{-1}$ and spacing of $0.45 \mathrm{~m}$ between rows. Seed inoculation was performed in the sowing furrow by applying Biomax ${ }^{\circledR}$ Premium Liquid Soybean inoculant at $360 \mathrm{~mL} \mathrm{ha}^{-1}$. The eucalyptus species used was a 2-year-old Eucalyptus grandis $\mathrm{x}$ E. camaldulensis (Camaldugrandis) hybrid, planted in a double row with $22 \mathrm{~m}$ spacing between rows, in the east-west direction. 


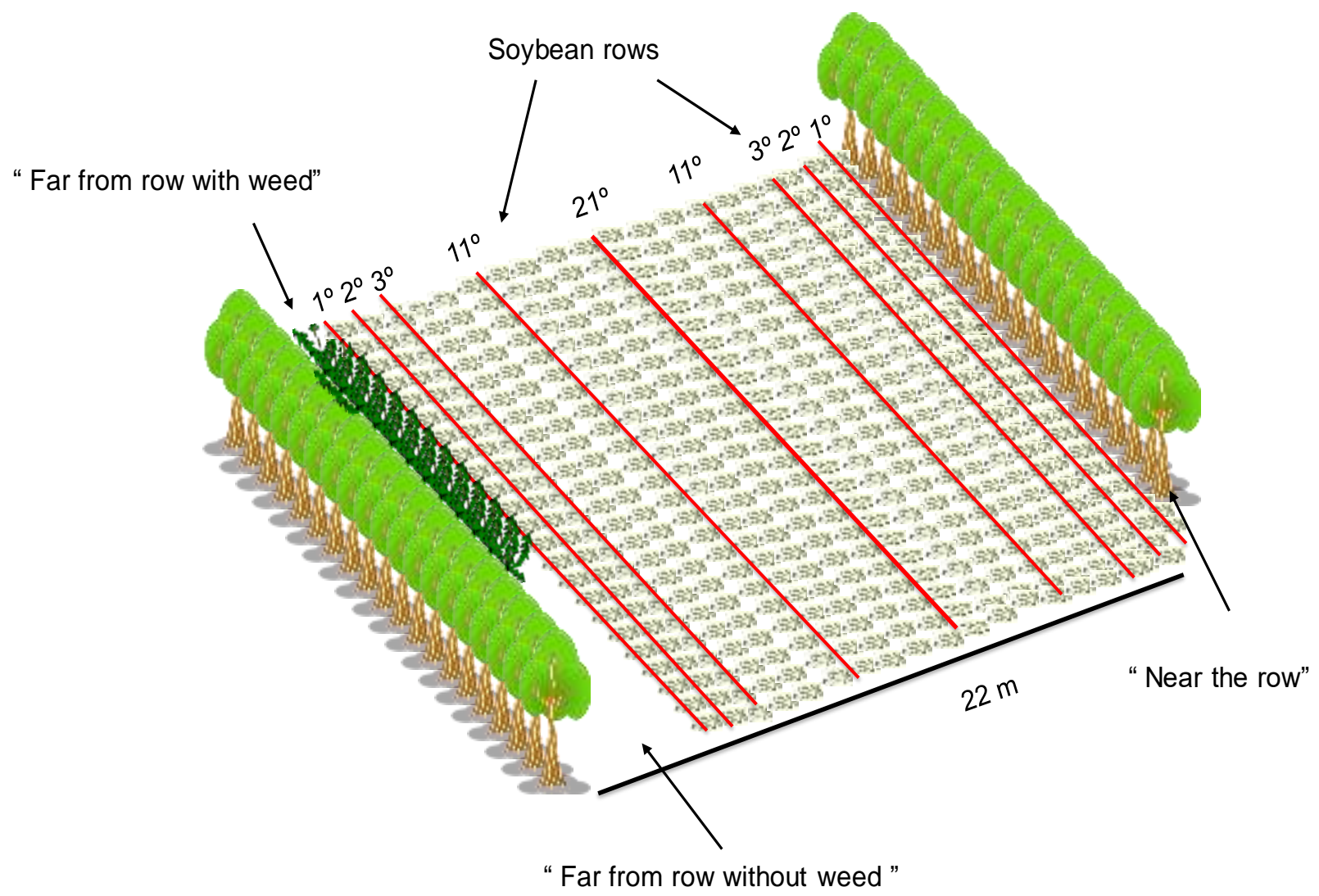

Figure 1 - Detail of treatment distribution in the experimental area.

Weeds were eliminated before sowing by applying the herbicide glyphosate at $740 \mathrm{~g}$ ai ha-1, which allowed the soybean crop to be established without weeds. For the soybean crop and for soybean plants sown $3.0 \mathrm{~m}$ away from the stands with subsequent weed control ("clean"), weeds were managed by associating the herbicides ethyl chlorimuron at $100 \mathrm{~g}$ ai ha- ${ }^{-1}$ and lactofen at $120 \mathrm{~g}$ ai ha- ${ }^{-1}$, applied at 25 days after emergence of soybean seedlings (DAE), in addition to the herbicide haloxyfop-p-methyl at $36 \mathrm{~g}$ ai ha-1 ${ }^{-1}$ applied at 33 DAE. Spraying was carefully done to prevent the herbicide syrup from reaching the canopy of eucalyptus plants.

Weeds were characterized by individually collecting and identifying all weed species present between the stands and the soybean crop at the end of the experimental period. The specimens were taken to the laboratory and dried in a forced air oven at $65{ }^{\circ} \mathrm{C}$ for three days. After this procedure, the accumulated dry matter of the collected species was determined with the aid of a $0.01 \mathrm{~g}$ precision scale.

The kinetics of maximum chlorophyll $\alpha$ fluorescence was evaluated with the aid of a handheld chlorophyll fluorometer (model OS-30p) to determine the photochemical efficiency of photosystem II ( Fv/Fm). Evaluations considered the third trifoliate from the top of the plant, and were carried out in the early hours of the morning to ensure the adaptation of leaves to the dark. Four evaluation points were considered along $10 \mathrm{~m}$ of each row, analyzing three plants at each point, totaling 12 plants per row.

To evaluate the nodulation of soybean plants, we followed the methodology proposed by Brandelero et al. (2009) and collected plants along $10 \mathrm{~m}$ of each row, within 4 sampling points, each composed of 3 plants. The samples were taken to the laboratory where the number of branches per plant was counted and the shoots and roots separated. Then, we separated and counted the nodules present in the roots of soybean plants. The nodules and all material obtained in the shoots were placed separately in paper bags and kept in a greenhouse with forced air circulation at $65^{\circ} \mathrm{C}$ for 72 hours to determine the dry matter of these plant fractions. All these procedures were performed when at least $50 \%$ of the plants reached the phenological stage R5.

At the end of the experimental period, when the crop reached the harvest point (stage R9), soybean plants present in the $10 \mathrm{~m}$ section of each row were manually collected within 4 sampling points, being then properly threshed. The obtained grains were weighed in a $0.01 \mathrm{~g}$ precision scale and, thus, we obtained the yield in $\mathrm{kg} \mathrm{ha}^{-1}$ and the 100 grain weight of soybean, both variables corrected to $13 \%$ moisture.

The results were analyzed by the $\mathrm{F}$ test and the effects of treatments compared by the Scott-Knott test at $5 \%$ probability using the AgroEstat statistical program (Barbosa \& Maldonado Jr., 2015). 


\section{Results and discussion}

Evaluations carried out during the experimental period showed the presence of four eudicotyledonous weed species. From the data on dry matter $\left(\mathrm{g} \mathrm{m}^{-2}\right)$ accumulation by weeds, it can be seen that the species present in the area had high dry matter production and could compete with the soybean crop and use common resources such as water, light, and nutrients. Species Sida santaremnensis and Senna obtusifolia stood out for dry matter accumulation compared to the other species (Table 1).

Table 1 - List of species and dry matter $\left(\mathrm{g} \mathrm{m}^{-2}\right)$ accumulated by weeds during experimental period.

\begin{tabular}{llc}
\hline Common name & \multicolumn{1}{c}{ Species } & Dry mass $\left(\mathrm{g} \mathrm{m}^{-2}\right)$ \\
\hline Guanxuma & Sida santaremnensis H. Monteiro & 1532 \\
Fedegoso & Senna obtusifolia (L.) H.S. Irwin \& Barneby & 728 \\
Mata pasto & Diodia Teres Walter & 28 \\
Malva relógio & Sida carpinifolia (L) & 50 \\
\hline Total & & 2238 \\
\hline
\end{tabular}

In this study, S. santaremnensis had the largest relative amount of environmental resources transformed into dry matter throughout the experiment. As a result, it was considered as the weed that most competed with the soybean crop, consequently influencing its productive characters. This finding can be explained since this species is characterized by being a perennial weed with high nutrient absorption capacity when compared to other species (Soares et al., 2015).

Species $S$. obtusifolia also allocated a large amount of dry matter and also established a strong competitive pressure on the soybean crop. It is noteworthy that $S$. obtusifolia is an annual weed that has as its main characteristic a fast initial growth, with strong competition in the early development of annual crops such as soybeans (Marchi et al., 2017). According to Wandscheer et al. (2014), weeds with early emergence, high seedling vigor, dense canopy formation, high height, and long development cycle are considered to be better competitors.

The efficiency of the photosynthetic apparatus of soybean plants ( $F v / F m)$ was little affected by sowing conditions, and significant reductions were observed only when weeds ("vegetation" condition) were present in the first planting row (Table 2).

Table 2 - Effect of condition and planting proximity on the photosystem Il quantum efficiency $(F v / F m)$ of soybean plants.

\begin{tabular}{lccc}
\hline Line & Near & Fv/Fm & \\
& & Far & Vegetation \\
1 & $0.632 \mathrm{Aa}$ & $0.659 \mathrm{Aa}$ & $0.604 \mathrm{Bb}$ \\
2 & $0.639 \mathrm{Aa}$ & $0.652 \mathrm{Aa}$ & $0.632 \mathrm{Aa}$ \\
3 & $0.649 \mathrm{Aa}$ & $0.643 \mathrm{Aa}$ & $0.645 \mathrm{Aa}$ \\
11 & $0.631 \mathrm{Aa}$ & $0.646 \mathrm{Aa}$ & $0.654 \mathrm{Aa}$ \\
21 & $0.649 \mathrm{Aa}$ & $0.658 \mathrm{Aa}$ & $0.640 \mathrm{Aa}$ \\
\hline Variation sources & & $\mathrm{F}$ values & \\
\hline Condition (C) & & $3.80^{*}$ & \\
Line (L) & & $1.36^{\mathrm{NS}}$ & \\
C x L & & $1.85^{*}$ & \\
Block & & 14.13 & \\
\hline C.V. (\%) & & 3.06 & \\
\hline
\end{tabular}

NS - Not significant. * Significant to $F$ test $(p<0.05)$. Means followed by the same uppercase letter in the column and lowercase in the row do not differ by Scott-Knott test $(p>0.05)$.

The competition between weeds and soybean plants for environmental resources was substantially harmful to the photochemical apparatus and chlorophyll $\alpha$ fluorescence $(F v / F m)$ of the soybean crop, since photosynthesis is extremely dependent on environmental factors such as light, temperature, $\mathrm{CO}_{2}$, water, and mineral nutrient availability (Corrêa \& Alves, 2010). Changes in the kinetics of maximum chlorophyl $\alpha$ fluorescence of photosynthetic organisms are the result of frequent changes in photosynthetic activity, especially regarding the quantum efficiency of electron transport through photosystem II in leaves, thus evidencing the disturbances caused by the competition imposed by weeds (Yusuf et al., 2010).

The "near" eucalyptus stands condition did not negatively influence the soybean crop variable Fv/Fm due to the spatial arrangement of the integration system. The stands were planted in the east-west direction, so there was a higher incidence of light and practically no shading over the crop established between them (Almeida et al., 2014).

The number of branches of soybean plants 
was significantly affected by the proximity to eucalyptus stands and by the presence of weeds only in the first planting row. Considering only the row factor, no significant effects were observed under any of the imposed conditions. The "vegetation" condition also influ- enced the shoot dry matter production of soybean plants in the first three planting rows. For soybean sown "near" eucalyptus stands, the first and second rows showed a significant reduction in dry matter production (Table 3).

Table 3 - Effect of condition and planting proximity on the number of branches and shoot dry matter of soybean plants.

\begin{tabular}{|c|c|c|c|}
\hline \multirow{3}{*}{ Line } & \multicolumn{3}{|c|}{ Number of branches per plant } \\
\hline & Near & \multicolumn{2}{|c|}{ Far } \\
\hline & & Clean & Vegetation \\
\hline 1 & $12.0 \mathrm{Ab}$ & $15.2 \mathrm{Aa}$ & $11.0 \mathrm{Ab}$ \\
\hline 2 & $12.3 \mathrm{Aa}$ & $14.0 \mathrm{Aa}$ & $10.7 \mathrm{Aa}$ \\
\hline 3 & 13.7 Aa & $13.0 \mathrm{Aa}$ & $10.5 \mathrm{Aa}$ \\
\hline 11 & $13.5 \mathrm{Aa}$ & $12.5 \mathrm{Aa}$ & $11.8 \mathrm{Aa}$ \\
\hline 21 & 13.3 Aa & $13.5 \mathrm{Aa}$ & $12.0 \mathrm{Aa}$ \\
\hline Variation sources & \multicolumn{3}{|c|}{ F values } \\
\hline Condition $(\mathrm{C})$ & \multicolumn{3}{|c|}{$4.88^{*}$} \\
\hline Line $(\mathrm{L})$ & \multicolumn{3}{|c|}{$0.11^{\mathrm{NS}}$} \\
\hline$C \times L$ & \multicolumn{3}{|c|}{$0.60^{*}$} \\
\hline Block & \multicolumn{3}{|c|}{6.09} \\
\hline C.V. (\%) & \multicolumn{3}{|c|}{20.28} \\
\hline \multirow{2}{*}{ Line } & \multicolumn{3}{|c|}{ Shoot dry mass (g) } \\
\hline & Near & \multicolumn{2}{|c|}{ Far } \\
\hline & & Clean & Vegetation \\
\hline 1 & $109.0 \mathrm{Bb}$ & $132.0 \mathrm{Aa}$ & $96.8 \mathrm{Bb}$ \\
\hline 2 & $95.8 \mathrm{Bb}$ & 129.2 Aa & 100.5 Bb \\
\hline 3 & 127.7 Aa & $126.8 \mathrm{Aa}$ & 88.5 Bb \\
\hline 11 & $135.4 \mathrm{Aa}$ & 130.8 Aa & 119.3 Aa \\
\hline 21 & 135.2 Aa & 138.2 Aa & $126.5 \mathrm{Aa}$ \\
\hline Vatiation sources & \multicolumn{3}{|c|}{ F values } \\
\hline Condition (C) & \multicolumn{3}{|c|}{$5.29^{*}$} \\
\hline Line $(\mathrm{L})$ & \multicolumn{3}{|c|}{$5.30^{*}$} \\
\hline$C \times L$ & \multicolumn{3}{|c|}{$1.33^{*}$} \\
\hline Block & \multicolumn{3}{|c|}{1.28} \\
\hline C.V. (\%) & \multicolumn{3}{|c|}{16.25} \\
\hline
\end{tabular}

NS - Not significant. * Significant to F test $(p<0.05)$. Means followed by the same uppercase letter in the column and lowercase in the row do not differ by Scott-Knott $(p>0.05)$.

The presence of weeds reduces trifoliate formation and dry matter accumulation throughout the soybean cycle, with greater damage as infestation levels increase (Pittelkow et al., 2009). The proximity of the tree component to the first soybean planting rows influenced branch development and shoot dry matter production, supposedly due to competition for space and soil nutrients. When grown close to soybean, eucalyptus plants compete strongly for water and nutrients, depriving soybean plants of these fundamental resources for growth and formation of reproductive structures (Svoma et al., 2016).

The presence of weeds between eucalyptus stands and the soybean crop ("vegetation" condition) also negatively influenced the amount and dry matter production of nodules by soybean plants in the first and second row. Significant effects were observed when the crop was conditioned "near" eucalyptus stands (Table 4).

Damage to the photochemical apparatus and chlorophyll $\alpha$ fluorescence of soybean caused by competition with weeds was critical in reducing the number and dry matter of nodules, as disturbances to the photosynthetic apparatus of plants can interfere with the size of roots and nodule production, making nitrogen absorption difficult and directly influencing yield (Gal et al., 2015).

Cultivation in the presence of weeds ("vegetation") also negatively influenced soybean yield in the first three planting rows, with a reduction of approximately $31 \%$ compared to the most distant planting rows. Yield in the "clean" planting condition (away from eucalyptus stands and without weeds) was practically uniform, with a significant contrast only in the first planting row, in which it was statistically superior to the other planting rows, which was possibly due to higher branch yield as a function of plant spatial arrangement. In turn, cultivation "near" eucalyptus stands significantly influenced soybean yield in the first two planting rows (Table 5). 
Table 4 - Effect of planting condition and proximity on the number and dry matter of nodules obtained at different growing conditions.

\begin{tabular}{|c|c|c|c|}
\hline \multirow{2}{*}{ Line } & \multicolumn{3}{|c|}{ Number of nodules per plant } \\
\hline & Near & \multicolumn{2}{|c|}{ Far } \\
\hline & & Clean & Vegetation \\
\hline 1 & $122.0 \mathrm{Aa}$ & 155.8 Aa & $76.0 \mathrm{Bb}$ \\
\hline 2 & $113.5 \mathrm{Aa}$ & 145.8 Aa & $74.8 \mathrm{Bb}$ \\
\hline 3 & $141.5 \mathrm{Aa}$ & $111.5 \mathrm{Aa}$ & $138.3 \mathrm{Aa}$ \\
\hline 11 & $148.0 \mathrm{Aa}$ & $124.0 \mathrm{Aa}$ & $134.5 \mathrm{Aa}$ \\
\hline 21 & $126.5 \mathrm{Aa}$ & $127.3 \mathrm{Aa}$ & $114.0 \mathrm{Aa}$ \\
\hline Variation sources & \multicolumn{3}{|c|}{ Fvalues } \\
\hline Condition (C) & \multicolumn{3}{|c|}{$2.72^{\mathrm{NS}}$} \\
\hline Line (L) & \multicolumn{3}{|c|}{$0.74^{\mathrm{NS}}$} \\
\hline$C \times L$ & \multicolumn{3}{|c|}{$1.64^{*}$} \\
\hline Block & \multicolumn{3}{|c|}{1.09} \\
\hline C.V. (\%) & \multicolumn{3}{|c|}{30.70} \\
\hline \multirow{2}{*}{ Line } & \multicolumn{3}{|c|}{ Dry mass of nodules $(\mathrm{g})$} \\
\hline & \multirow[t]{2}{*}{ Near } & \multicolumn{2}{|c|}{ Far } \\
\hline & & Clean & Vegetation \\
\hline 1 & $2.45 \mathrm{Ba}$ & $2.85 \mathrm{Aa}$ & $1.77 \mathrm{Ab}$ \\
\hline 2 & $2.27 \mathrm{Ba}$ & $2.68 \mathrm{Aa}$ & $1.78 \mathrm{Ab}$ \\
\hline 3 & $3.15 \mathrm{Aa}$ & $2.53 \mathrm{Aa}$ & $2.60 \mathrm{Aa}$ \\
\hline 11 & $2.08 \mathrm{Ba}$ & $1.80 \mathrm{Ba}$ & $1.88 \mathrm{Aa}$ \\
\hline 21 & $1.80 \mathrm{Ba}$ & $1.97 \mathrm{Ba}$ & $1.80 \mathrm{Aa}$ \\
\hline Variation sources & \multicolumn{3}{|c|}{ F values } \\
\hline Condition (C) & \multicolumn{3}{|c|}{$3.75^{*}$} \\
\hline Line (L) & \multicolumn{3}{|c|}{$5.82^{*}$} \\
\hline $\mathrm{C} \times \mathrm{L}$ & \multicolumn{3}{|c|}{$1.42^{*}$} \\
\hline Block & \multicolumn{3}{|c|}{1.99} \\
\hline C.V. (\%) & \multicolumn{3}{|c|}{23.53} \\
\hline
\end{tabular}

Table 5 - Effect of condition and planting proximity on yield and weight of 100 soybean grains obtained at different growing conditions.

\begin{tabular}{|c|c|c|c|}
\hline \multirow{2}{*}{ Line } & \multicolumn{3}{|c|}{ Yield $\left(\mathrm{kg} \mathrm{ha}^{-1}\right)$} \\
\hline & Near & \multicolumn{2}{|c|}{ Far } \\
\hline 1 & $2583.0 \mathrm{Bb}$ & $\begin{array}{c}\text { Clean } \\
3382.5 \mathrm{Aa}\end{array}$ & $\begin{array}{l}\text { Vegetation } \\
2020.3 \mathrm{BC}\end{array}$ \\
\hline 2 & 2475.3 Bb & $2789.7 \mathrm{Ba}$ & $2300.0 \mathrm{Bb}$ \\
\hline 3 & $2973.9 \mathrm{Aa}$ & 3013.3 Ba & $2526.7 \mathrm{Ab}$ \\
\hline 11 & $2720.8 \mathrm{Aa}$ & $2961.7 \mathrm{Ba}$ & $2961.7 \mathrm{Aa}$ \\
\hline 21 & $3152.6 \mathrm{Aa}$ & $2788.9 \mathrm{Ba}$ & $2694.8 \mathrm{Aa}$ \\
\hline Variation sources & \multicolumn{3}{|c|}{ Fvalues } \\
\hline Condition $(\mathrm{C})$ & \multicolumn{3}{|c|}{$11.25^{\star}$} \\
\hline Line $(\mathrm{L})$ & \multicolumn{3}{|c|}{$2.91^{*}$} \\
\hline$C \times L$ & \multicolumn{3}{|c|}{$4.55^{*}$} \\
\hline Block & \multicolumn{3}{|c|}{3.10} \\
\hline C.V. (\%) & \multicolumn{3}{|c|}{11.05} \\
\hline \multirow{2}{*}{ Line } & \multicolumn{3}{|c|}{ Weight of 100 grains $(\mathrm{g})$} \\
\hline & Near & \multicolumn{2}{|c|}{ Far } \\
\hline & & Clean & Vegetation \\
\hline 1 & $10.67 \mathrm{Ba}$ & $10.56 \mathrm{Ba}$ & $10.56 \mathrm{Ba}$ \\
\hline 2 & $10.62 \mathrm{Ba}$ & $10.60 \mathrm{Ba}$ & $10.60 \mathrm{Ba}$ \\
\hline 3 & 11.31 Aa & $10.40 \mathrm{Ba}$ & $10.40 \mathrm{Ba}$ \\
\hline 11 & $11.46 \mathrm{Aa}$ & $11.64 \mathrm{Aa}$ & $11.64 \mathrm{Aa}$ \\
\hline 21 & $11.62 \mathrm{Aa}$ & $11.50 \mathrm{Aa}$ & $11.50 \mathrm{Aa}$ \\
\hline Variation sources & \multicolumn{3}{|c|}{ F values } \\
\hline Condition (C) & \multicolumn{3}{|c|}{$1.17^{\mathrm{NS}}$} \\
\hline Line $(\mathrm{L})$ & \multicolumn{3}{|c|}{$8.98^{*}$} \\
\hline$C \times L$ & \multicolumn{3}{|c|}{$1.37^{*}$} \\
\hline Block & \multicolumn{3}{|c|}{2.37} \\
\hline C.V. (\%) & \multicolumn{3}{|c|}{4.39} \\
\hline
\end{tabular}


The 100 grain weight was little influenced by the experimental factors, since no significant contrast related to the sowing condition was observed. Notwithstanding, considering only the "planting row" factor, there was a significant difference in the 100 grain weight of soybean plants for the rows closest to eucalyptus stands, regardless of the imposed condition (Table 5).

In this experiment, the reduction in the number of reproductive branches and in the dry matter of soybean shoots due to the proximity to the tree component resulted in a significant loss of crop yield (approximately $19 \%$ loss). Corroborating this result, Werner et al. (2017) comment that in CFI systems, the closer the eucalyptus stands are, the lower the soybean growth and nitrogen accumulation in its dry matter due to competition for environmental resources, causing significant losses in grain yield.

Considering the high competitive pressure of weeds, the "vegetation" condition promoted the most severe effects in this experiment, since the observed reductions in yield, especially in the first row of soybean cultivation, were more significant than those observed in the "near" eucalyptus stands condition. According to Pittelkow et al. (2009), high weed infestations affect the number of pods per plant, grain weight, and grain yield, leading to yield losses.

\section{Conclusions}

Soybean cultivation carried out near eucalyptus stands does not interfere with the photochemical apparatus, chlorophyll $\alpha$ fluorescence, and the number and dry matter of nodules. Notwithstanding, this condition reduces the number of branches, shoot dry matter, and yield (by up to 19\%) in the first two planting rows compared to the most distant rows.

The presence of weeds in the range between stands and planting areas impaired the photochemical apparatus and the chlorophyll $\alpha$ fluorescence of soybean, decreasing the shoot dry matter accumulation, number and dry matter of nodules, and yield of the plants present in the first planting rows.

\section{References}

Almeida FD, Calonego JC, Catuchi TA, Tiritan CS, Araújo FF, Silva PCG (2014) Produtividade de soja em diferentes posições entre renques de eucalipto em cultivo consorciado. Colloquium Agrariae 10(1):33-44. DOI: 10.5747/ca.2014.v10.n1.a098

Balbino LC, Cordeiro LAM, Porfirio-Da-Silva V, Moraes A, Martinez GB, Alvarenga RC, Kichel AN, Fontaneli RS, Santos HP, Franchini JC, Galerani PR (2011) Evolução tecnológica e arranjos produtivos de sistemas de integração lavoura-pecuária-floresta no Brasil. Pesquisa Agropecuária Brasileira 46(10):1-7. DOI: 10.1590/S0100-204X2011001000001
Barbosa JC, Maldonado Jr. W (2015) Experimentação agronômica \& AgroEstat: Sistemas para análises estatísticas e ensaios agronômicos. Jaboticabal: Gráfica Multipress Ltda. 396p.

Brandelero EM, Pereira Peixoto C, Ralisch R (2009) Nodulação de cultivares de soja e seus efeitos no rendimento de grãos. Semina: Ciências Agrárias, 30(3):581-588.

Corrêa MJP, Alves PLDCA (2010) Effects of herbicides application on photochemical efficiency in conventional and genetically modified soybeans. Ciência e Agrotecnologia 34(5):1136-1145. DOI: 10.1590/S141370542010000500009

Diel $D$, Behling $M$, Farias Neto $A L$, Isernhagen ECC (2014) Distribuição horizontal e vertical de fósforo em sistemas de cultivos exclusivos de soja e de integração lavoura-pecuária-floresta. Pesquisa Agropecuária Brasileira 49(8):639-647. DOI: 10.1590/S0100-204X2014000800008

Franchini JC, Balbinot Junior AA, Sichier, F, Debiasi H, Conte O (2014) Yield of soybean, pasture and wood in integrated crop-livestock-forest system in Northwestern Paraná state, Brazil. Revista Ciência Agronômica 45(5):1006-1013. DOI: 10.1590/S180666902014000500016

Gal J, Afifi M, Lee E, Lukens L, Swanton CJ (2015) Detection of neighboring weeds alters soybean seedling roots and nodulation. Weed Science 63(4):888-900 .

Macedo MCM (2009) Integração lavoura e pecuária: o estado da arte e inovações tecnológicas. Revista Brasileira de Zootecnia 38(Suplemento Especial):133$-146$.

Marchi SR, Bellé JR, Foz CH, Ferri J, Martins D (2017) Weeds alter the establishment of Brachiaria brizantha cv. Marandu. Tropical Grasslands-Forrajes Tropicales 5(2):85-93.

Moraes PVD, Agostinetto D, Galon L, Rigoli RP (2009) Competitividade relativa de soja com arroz-vermelho. Planta Daninha 27(1):35-40.

Pittelkow FK, Jakelaitis A, Conus LA, Oliveira AA, Gil JO, Assis FC, Borchartt L (2009) Interferência de plantas daninhas na cultura da soja transgênica. Global Science and Technology 2(3):38-48.

Soares MRS, Neto ACA, São Jose AR, Cardoso AD, Morais OM, Lima RS, Moreira ES, Prado TR (2015) Weed dry mass accumulation in response to the application of NPK fertilizers in cassava crop. African Journal of Agricultural Research 10(36):3596-3606. 
Soratto RP, Rosolem CA, Crusciol CAC (2011) Integração Lavoura-Pecuária-Floresta. Botucatu, SP, Editora FEPAF. 110p.

Svoma BM, Fox N, Pallardy Q, Udawatta RP (2016) Evapotranspiration differences between agroforestry and grass buffer systems. Agricultural Water Management 176:214-221.

Tonini H, Morales MM, Meneguci JLP, Antonio DBA, Wruck FJ (2016) Biomass and leaf area in eucalyptus clones in Crop-Livestock-Forestry Systems: implications for pruning. Nativa 4(5):271-276. DOI: $10.14583 / 2318-7670 . v 04 n 05 a 02$

Wandscheer ACD, Rizzardi MA, Reichert M, Gaviraghi F (2014) Capacidade competitiva da cultura do milho em relação ao capim-sudão. Revista Brasileira de Milho e Sorgo 13(2):129-141. DOI: 10.18512/19806477/rbms.v13n2p129-141
Werner F, Balbinot Junior AA, Franchini JC, Ferreira AS (2017) Agronomic performance of soybean cultivars in an agroforestry system. Pesquisa Agropecuária Tropical 47(3):279-285. DOI: 10.1590/1983$40632016 v 4745937$

Wink C, Lange A, Araujo KZ, Almeida APS, Behling M, Wruck FJ (2018) Biomass and nutrients of eucalyptus cultivated in agrossilvipastoral system. Nativa 6:754762. DOI: 10.31413/nativa.v6i0.5987

Yusuf MA, Kumar D, Rajwanshi R, Strasser RJ, Tsimilli-Michael M, Sarin NB (2010) Overexpression of $\mathrm{Y}$-tocopherol methyl transferase gene in transgenic Brassica juncea plants alleviates abiotic stress: physiological and chlorophyll a fluorescence measurements. Biochimica et Biophysica Acta (BBA)-Bioenergetics 1797(8):1428-1438. 